(C) 2017, Elsevier. Licensed under the Creative Commons Attribution-NonCommercial-NoDerivatives 4.0 International http://creativecommons.org/licenses/by-nc-nd/4.0/

\title{
PSYCHOLOGICAL CONTRACT VIOLATION AND CUSTOMER INTENTION TO REUSE ONLINE RETAILERS: EXPLORING MEDIATING AND MODERATING MECHANISMS
}

\section{Neeru Malhotra, Sunil Sahadev and Keyoor Purani}

\begin{abstract}
This study examines the impact of psychological contract violation (PCV) on customer intention to reuse online retailer websites via the mediating mechanisms of trust and satisfaction. The moderating role of perceived structural assurance (SA) is also investigated. An empirical study conducted among online shoppers confirms the indirect effects of PCV on customers' intention to reuse via trust and satisfaction. The findings also support the moderating impact of perceived SA in the network of relationships. The study underscores the importance of SA as a trust-building mechanism for mitigating the deleterious effects of PCV among online customers, although the role of SA in preserving satisfaction is found to be limited. The findings suggest that online retailers may benefit by investing in SA and addressing the negative effects of PCV proactively rather than simply relying on post-failure service recovery mechanisms.
\end{abstract}

\section{Keywords}

psychological contract violation (PCV); trust; customer satisfaction; structural assurance; intention to reuse; online retailing 


\section{PSYCHOLOGICAL CONTRACT VIOLATION AND CUSTOMER INTENTION TO REUSE ONLINE RETAILERS: EXPLORING MEDIATING AND MODERATING MECHANISMS}

\section{Introduction}

Online retailing is rapidly emerging as an alternative to traditional brick and mortar retailing across a host of product categories throughout the world (Richard \& Chebat, 2016; Smith et al., 2013). The literature argues that every buyer-seller interaction in the online marketplace can be characterized by the psychological contract (Pavlou \& Gefen, 2005; Theotokis et al., 2012), as online buyers are generally governed by their implicit understanding of the seller's transactional obligations rather than by the explicit rules in legal contracts (Pavlou \& Gefen, 2005). Psychological contracts are based on perceived promises, and arise when one party believes that another party is obligated to perform certain behaviours (Rousseau, 1995). From a buyer's perspective, psychological contracts comprise the buyer's perceptual beliefs about the seller's contractual obligations. Thus, buyers' individual perceptions of psychological contract violation (PCV), which arise if they think they are not getting what has been promised by a contractual agreement, are considered to be the most relevant for understanding and predicting their behaviour in online marketplaces (Pavlou \& Gefen, 2005; Theotokis et al., 2012).

While the literature has established the negative effects of PCV on employee trust, satisfaction, commitment, and retention within the context of the employee-organization relationship (Bal et al., 2008; Niehoff \& Paul, 2001; Zhao et al., 2007), few studies have explored its impact and relevance in buyer-seller relationships. Despite the extensive research on service failures and their interaction with service recovery (e.g. McCollough et al., 2000; Smith et al.,1999; Weun et al., 2004) and perceived justice (Smith et al., 1999; Tax et al., 
1998; Wang et al., 2011), 'little attention has been given to how service failures influence customer-company relationships' (Sajtos et al., 2010, p. 216), especially in online environments (Holloway \& Beatty, 2003; Sousa \& Voss, 2009; Wang et al., 2011). In this context, most studies focus on analysing the negative impact of either the type (Meuter et al., 2000; Smith \& Bolton, 1998; Surachartkumtonkun et al., 2013) or severity of service failures (Sajtos et al., 2010; Wang et al., 2011) on customer attitudes and behaviours. As PCV damages the bond between the customer and the company created by the psychological contract, we propose that PCV may provide a better explanation of how service failures may influence customer-company relationships. While injustice dimensions have been studied as a surrogate for PCV (e.g. Fang \& Chiu, 2014), specific research on the role and impact of PCV from the psychological contract theory perspective in online contexts remains scant. Given the deleterious effects of PCV within organizational relationships, such an investigation is vital, especially as the literature suggests that service failure and PCV are closely related yet different concepts (see Goles et al., 2009; Wang \& Huff, 2007).

Service failures can be understood as unfavourable service encounters that lead to customer dissatisfaction (Bitner et al., 1990). Palmer et al. (2000) define service failure as 'any situation where something has gone wrong, irrespective of responsibility' (p. 515). Hence, service failure is an unmet expectation, where the responsibility is unknown (Goles et al., 2009). While customers understand and may be willing to accept that service failures are inevitable (Joireman et al., 2013), customers experience psychological contract violation when the responsibility for the service failure can be directly attributed to the trustee (i.e. seller) (Goles et al., 2009). Thus, in a buyer-seller relationship, PCV occurs when the buyer perceives that the seller's failure violated a psychological contract between the seller and the buyer (Wang \&Huff, 2007). As psychological contracts are promissory in nature, unlike expectations, both real and perceived instances of unmet expectations can lead to violations 
of psychological contracts (Rousseau \& Tijoriwala, 1998). Therefore, PCV could be caused by actual contract violations or by misunderstandings regarding what the contractual obligations are, often referred to as (respectively) 'reneging' or 'incongruence' (see Pavlou \& Gefen, 2005). Thus, buyers may perceive PCV even when the explicit contract rules may not have been violated; on the other hand, buyers may not perceive PCV even if certain legal obligations are breached. For example, a buyer may acknowledge an unethical act by the seller but consider it a trivial matter and hence may not experience PCV (see Hill et al., 2009). As explained by Niehoff and Paul (2001), only salient problems typically result in PCV. Moreover, PCV can be prevented via ex post problem resolution (Pavlou \& Gefen, 2005). In this context, the literature indicates that those seller behaviours that suggest a sense of betrayal lead to buyers' PCV perceptions most often (Goles et al., 2009). Thus, PCV is seen to have repercussions that are more intense and significant than those of unmet expectations (Robinson \& Rousseau, 1994) because 'the intensity of the reaction is attributable not only to unmet expectations of specific rewards or benefits, but also to more general beliefs about respect for persons, codes of conduct, and other patterns of behavior associated with relationships' (Robinson \& Rousseau, 1994, p. 247). Since buyer behaviour in online marketplaces is guided mainly by their subjective perceptions of PCV (Pavlou \& Gefen, 2005), it is vital to understand how PCV influences customer loyalty, which may be more important in e-services than in comparable, traditional services (Reichheld \& Schefter, 2000). Consequently, calls have been made for more research in an effort to understand the challenges induced by PCV, and how these could be overcome in online retail environments (Goles et al., 2009; Lövblad et al., 2012; Pavlou \& Gefen, 2005).

Despite the empirical studies on the impact of PCV on trust in online retail environments - in which PCV is demonstrated to negatively influence trust among online buyers (e.g. Goles et al., 2009; Pavlou \& Gefen, 2005) - studies on the effects of PCV on 
online buyers' overall satisfaction are negligible. As trust and satisfaction are considered the two key 'stepping stones' for successful e-commerce B2C relationships that can influence buyers' repurchase intentions directly (Kim et al., 2009), how PCV affects both trust and satisfaction warrants further research attention.

Moreover, little is known about how the adverse effects of PCV can be mitigated, a question of both practical and theoretical significance in e-retailing environments, where PCV seems inevitable (Pavlou \& Gefen, 2005) and online customers experiencing PCV can exit the relationship simply by the click of a mouse (Holloway \& Beatty, 2003). Since online shopping interaction does not take place at the retailer's location and as the e-retailer cannot control all aspects of customer experience formation (Verhoef et al., 2009), structural assurance (SA) may play a crucial role, as it enhances the perceived security of the online trading environment (Balsubramanian et al., 2003). However, empirical research on the role of SA in the event of PCV remains scant (Hogreve \& Gremler, 2009); more research is therefore required to examine the complex moderating role of SA in buyer-seller relationships (Gefen \& Pavlou, 2012).

Extending PCV theory (Rousseau, 1995) and the stimulus-organism-response (S-OR) framework (Mehrabian \& Russell, 1974) to buyer-seller relationships in online marketplaces, this study develops and tests a conceptual framework to address the abovementioned research gaps and makes three important contributions to the e-retailing literature. First, this study extends the limited research on PCV in the e-retailing context and identifies the key mediating mechanisms underlying the relationship between PCV and a buyer's intention to reuse the e-retailer's website. Second, this study investigates the underresearched impact of PCV on the psychological states of customers and, in particular, explores the neglected relationship between PCV and customer satisfaction. Third, while most of the retailing literature emphasises firms' reactive post-failure recovery strategies (c.f. 
Brady et al., 2008; Joireman et al., 2013; Smith et al., 1999; Tax et al., 1998; Tokman et al., 2007), this study investigates how proactive strategies such as SA may help to mitigate the negative effects of PCV. Investments in SA are especially useful for online retail environments, as they are likely to strengthen customers' beliefs about positive recovery expectancy (Pavlou \& Gefen, 2004). Although interventions such as service guarantees, commitment, customer choice, and brand personality are suggested to have 'dampening effects' on negative customer experiences, mainly in traditional service settings (see Brady et al., 2008), no previous study has empirically investigated how SA moderates the effects of PCV in the e-retailing context.

This empirical study is conducted among shoppers in the Indian e-retailing context because India is now home to the largest online user base after China (Verma, 2015). India has seen an unprecedented growth in its e-retailing sector in the last decade (Nair, 2013), with an approximate combined annual growth rate (CAGR) of 21\% (Euromonitor, 2016). From a modest market size of $\$ 5$ billion in 2015 , the total online-retail market is expected to grow to a value of $\$ 130$ billion by 2025 (Balachandar, 2015). However, despite India's phenomenal eretailing growth, its e-retailing sector is plagued by persistent problems related to logistics and cash-on-delivery (COD) systems (see Hartley \& Walker, 2013; Pandey et al., 2015). Thus, instances of PCV, regarding delivery delays, reliability of the quality of goods delivered, and financial loss or fraud in transactions, are quite common and continue to inhibit the expansion of the Indian e-retailing sector (Pandey et al., 2015). Thus, given India's growing global economic e-tailing impact and recent calls in the literature to investigate eretailing issues in such developing-country contexts (Chen et al., 2015; Jin et al., 2008; Rose et al., 2012; Smith et al., 2013), this study is likely to be of interest to both researchers and practitioners. 
The structure of the paper is as follows. First, a conceptual framework is developed and tested using a large-scale survey of online customers. Then, empirical results are presented and discussed. Next, managerial implications are discussed, along with the limitations of the study and suggestions for future research directions.

\section{Conceptual framework}

This study draws on the S-O-R model developed by Mehrabian and Russell (1974), which has been applied in various retail settings, to explain consumer decision making (Jang \& Namkung, 2009; Yi \& Gong, 2009), including online retailing (Kim \& Lennon, 2010; Richard \& Chebat, 2016; Wang et al., 2010). Within the S-O-R framework, the environment contains a stimulus (S), which influences the internal, organismic states of the individual $(\mathrm{O})$, which, in turn, cause approach or avoidance responses (R). Thus, the organism, represented by cognitive and affective intermediary states, mediates the relationships between the stimulus and the individual's responses.

According to the S-O-R framework, the stimulus affecting the internal, organismic states of the individual mainly comprises environmental stimuli such as atmospherics, store environment, and website design quality (see Vieira, 2013). However, researchers have begun to extend Mehrabian and Russell's framework by incorporating other intangible stimuli into the model, as these stimuli are also expected to trigger a change in the state of an organism. It is argued that environmental stimuli are only a subset of the overall service stimuli and may therefore provide only limited information concerning customer evaluations of perceived quality in service settings (Jang \& Namkung, 2009; Namkung \& Jang, 2010), where other aspects of service stimuli may have crucial roles to play. For example, Jang and Namkung (2009) apply the S-O-R model in a restaurant setting and argue that customer perceptions of service quality can also be classified as a stimulus. In another study (Namkung \& Jang, 
2010), perceived service fairness is taken as the core emotional elicitor (i.e. stimulus in the S$\mathrm{O}-\mathrm{R}$ model). The researchers argue that individuals' perceptions of injustice are likely to provoke emotional reactions, as emotions associated with consumption are formed in response to a specific consumer appraisal (Bagozzi et al., 1999). Thus, in the e-retail setting, customer perceptions of PCV, which occur when customers perceive the e-retailer to have failed to fulfil promised obligations, are a key stimulus that can influence the internal, organismic states of the customer because broken promises produce anger, lead to dissatisfaction, and erode trust in the relationship (Pavlou \& Gefen, 2005; Robinson \& Rousseau, 1994; Xiao \& Benbasat, 2011). For example, extending the S-O-R model to the online context, Fang and Chiu (2014) demonstrate that customer perceptions of PCV act as key stimuli that can elicit emotional reactions in customers, which, in turn, influence their switching behaviours.

Although most studies in environmental psychology focus on the pleasure-arousaldominance (PAD) dimensions of emotional response (Vieira, 2013), this approach has been criticised as being too narrow in scope (Eroglu et al., 2001). Instead, the literature has incorporated both trust and satisfaction as key psychological, organismic states, which are identified as key mediators in the S-O-R framework that directly influence customers' behavioural intentions (e.g. see Chang \& Chen, 2008; Harris \& Goode, 2010; Kim \& Lennon, 2010; Wang et al., 2010). Since the psychological contract theory literature demonstrates that PCV negatively affects both trust and satisfaction (Bal et al., 2008; Sels et al., 2004; Zhao et al., 2007), we study trust and satisfaction as key psychological states directly influenced by the PCV stimulus.

According to Mehrabian and Russell (1974), the organism's response is a variety of approach-avoidance behaviours such as intentions to stay or revisit (Yi \& Gong, 2009). A recent literature review on the S-O-R model conducted by Kawaf and Tagg (2012) 
demonstrates that the most popular element studied as a response to exposure to online stimuli is behavioural intention - the degree to which an individual has conscious plans to perform or not perform some specified behaviour (Jang \& Namkung, 2009). As behavioural intentions are a surrogate indicator of actual behaviour (Fishbein \& Ajzen, 1975), research extending PCV theory to buyer-seller relationships in online contexts (Goles et al., 2009; Pavlou \& Gefen, 2005) has shown that PCV affects buyers' transaction/repurchase intentions via trust. Hence, this study takes 'intention to reuse' as the key outcome variable.

Thus, the literature indicates that experiencing an unpleasant event negatively affects consumers' psychological states, which, in turn, directly affects their behavioural intention (i.e. a response) to use a service (Bagozzi, 1992; Bagozzi et al., 1999). Hence, drawing on the S-O-R model and the PCV theory literature, this study develops a conceptual framework (see Figure 1) and examines how PCV (stimulus) affects consumers' trust and satisfaction (organism) which, in turn, influence consumer intention to reuse (response). As the organism is suggested to intervene between the stimuli and the final responses (Bagozzi, 1986), this paper suggests that the effect of PCV on a customer's intention to reuse a retailer's website is likely to be mediated by both trust and satisfaction. However, the literature also suggests that trust affects satisfaction (Harris \& Goode, 2004; Ratnasingham, 1998). Hence, these psychological states may function as a causal chain, in a model referred to as 'serial mediation' (Hayes, 2013). For example, PCV could affect trust, trust could influence satisfaction, and satisfaction could predict reuse intentions $(\mathrm{PCV} \rightarrow$ trust $\rightarrow$ satisfaction $\rightarrow$ intentions to reuse). We thus investigate serial mediation, as the differential impact of trust and satisfaction could be indicative of an underlying causal chain.

\section{Research hypotheses}

\subsection{Psychological Contracts}


Contracts are essential in buyer-seller relationships and comprise two key components: legal and psychological. Rousseau and Tijoriwali (1998, p. 679) define the psychological contract as 'an individual's belief in mutual obligations between that person and another party'. A psychological contract is an assumed set of reciprocal obligations between two parties in an exchange relationship (Robinson \& Rousseau, 1994). Psychological contracts, unlike expectations, are based on perceived promises of reciprocal exchange and occur when one party believes that another party is obligated to perform certain behaviours (Rousseau, 1995). Hence, psychological contracts are much broader than economic and legal contracts, as they comprise several perceptual aspects that cannot be formally incorporated into legal contracts. Psychological contracts can be either transactional or relational (Rousseau, 1995; Rousseau \& Tijoriwala, 1998). Transactional contracts are more explicit than relational contracts and describe each party's contractual obligations. Given the transactional nature of buyer-seller relationships in online marketplaces and their relatively explicit contractual obligations (Pavlou \& Gefen, 2005), this paper focuses on transactional contracts.

\subsection{PCV}

The psychological contract theory literature suggests that violations are inevitable within contractual relationships (Rousseau, 1995). 'A violation occurs when one party in a relationship perceives another to have failed to fulfil promised obligation(s)' (Robinson \& Rousseau, 1994, p. 247). While PCV has been studied mainly in the context of employeeorganization relationships, Pavlou and Gefen (2005) examine PCV in buyer-seller relationships. They argue that every buyer-seller interaction can be characterized by the psychological contract that features the buyer's perceptual beliefs about the seller's contractual obligations, which may not be included in the formal legal terms of the exchange 
(Pavlou \& Gefen, 2005; Theotokis et al., 2012). PCV occurs when buyers perceive that the seller has failed to fulfil one or more obligations composing the psychological contract when buyers are not getting what has been promised by the contractual agreement (Niehoff \& Paul, 2001; Theotokis et al., 2012). Thus, PCV refers to the buyer's perception of having been treated wrongly regarding the terms of an exchange agreement with a seller (Pavlou \& Gefen, 2005). Psychological contract violation is common in online marketplaces because buyers and sellers do not engage at a personal, face-to-face level, are rarely familiar with each other, often have incongruent goals, and may have different understanding of their respective contractual obligations. As online buyers' behaviours are mainly guided by their perceptions of psychological contracts (Pavlou \& Gefen, 2005), PCV is central to our understanding of buyer-seller relationships in e-retailing.

Pavlou and Gefen (2005) identify four basic seller obligations constituting the basis of psychological contracts in online marketplaces: 1) deliver the product purchased in a timely manner by the promised method; 2) deliver an item that is identical to the one described and shown in the advertisement; 3) follow the payment policy promised and accept payment from the buyer; and, 4) follow the conditions of sale and honour a return or refund promise. Accordingly, Pavlou and Gefen (2005) identify seller behaviours such as fraud, product misrepresentation, contract default, product delivery delay, failure to acknowledge product guarantees, and refusal to follow payment policy as common underlying sources of PCV in online marketplaces. Since these underlying sources of PCV are not necessarily related, and any of these seller behaviours can either single-handedly or in some combination lead to the perception of PCV, Pavlou and Gefen (2005) propose that PCV is operationalised as a formative first-order construct formed by buyer perceptions of these common sources of PCV with the seller. Pavlou and Gefen (2005) advocate a formative PCV model to accurately and parsimoniously capture the multidimensional nature of PCV in an online context. In 
particular, an online buyer may perceive PCV if the e-retailer fails to adequately fulfil its contractual obligations due to fraud, product misrepresentation, contract default, delivery delay, or default on product guarantees and payment policies (Pavlou \& Gefen, 2005).

The psychological contract theory literature suggests that PCV leads to negative outcomes. The PCV process has been widely studied in the organizational behaviour literature with studies demonstrating its negative effects on employee attitudes such as trust and job satisfaction (Bal et al., 2008; Sels et al., 2004; Zhao et al., 2007). Extending such notions of PCV theory to online retailing, we believe that PCV is likely to negatively influence both trust and satisfaction among online customers. Since psychological states directly influence behaviour (Bagozzi et al., 1999), it is important to understand how PCV may affect both the trust and satisfaction of buyers in e-retail environments.

\subsubsection{PCV and Trust}

Trust is defined as a 'psychological state comprising the intention to accept vulnerability based on positive expectations of the intentions or behavior of another' (Rousseau et al., 1998, p. 395). Trust is regarded as a crucial enabling factor facilitating exchange relationships characterized by uncertainty, vulnerability, interdependence, and fear of opportunism, as is the case in online markets (Pavlou \& Gefen, 2004). Hence, trust is considered a crucial aspect of e-commerce (Pavlou \& Gefen, 2005; Kim et al., 2009). In the context of online buyer-seller relationships, trust refers to a consumer's subjective belief that the online vendor will fulfil the transactional obligations as the consumer understands them (Kim et al., 2009). As trust is based on confidence in the partner's ability to perform as expected, PCV is likely to influence trust negatively (Kingshott \& Pecotich, 2007) because it shows that the trustees have failed to meet their obligations (Niehoff \& Paul, 2001; Pavlou \& Gefen, 2005). Psychological contract violation raises doubts in the minds of the buyer about 
the seller's original intention to build and maintain a mutually beneficial relationship and may reduce the predictability of the seller's future actions (Robinson \& Rousseau, 1994). Thus, PCV erodes the trust that online buyers have in the internet retailer, as it ruins buyers' beliefs that online retailers will behave in a manner consistent with their confident expectations (Goles et al., 2009; Pavlou \& Gefen, 2005). Accordingly, the following is hypothesised:

H1: Psychological contract violation negatively influences trust

\subsubsection{PCV and Satisfaction}

Customer satisfaction is defined as the 'summary psychological state resulting when the emotion surrounding disconfirmed expectations is coupled with the consumer's prior feelings about the consumption experience' Oliver (1981, p. 29). According to Bhattacharjee (2001), this definition highlights a 'psychological or affective state related to and resulting from a cognitive appraisal of the expectation performance discrepancy (confirmation)' (p. 354). Thus, it seems logical to believe that PCV, a discrepancy between promised and received inducements, is likely to lead to feelings of dissatisfaction (Lövblad et al., 2012; Zhao et al., 2007) because a disconfirmatory experience such as PCV is likely to change the buyer's mindset from that of initial favourable belief to a negative affect (Pavlou \& Gefen, 2005). As satisfaction is primarily a function of the perceived relationship between what one expects and what one perceives as the offering (Oliver, 1981), PCV as an outcome of unmet obligations is likely to impact buyers' satisfaction negatively. Although the organizational behaviour literature demonstrates that PCV is strongly related to a decrease in employee satisfaction (Bal et al., 2008), research on the impact of PCV on customers' overall satisfaction in e-retail environments is scant. However, applying the above logic to online marketplaces, the following is hypothesised: 
H2: Psychological contract violation negatively influences satisfaction

\subsubsection{Trust and Satisfaction}

The literature on online settings finds trust to be a strong predictor of satisfaction (Balasubramanian et al., 2003; Harris \& Goode, 2004; Jin et al., 2008; Ratnasingham, 1998). Trust is suggested to be a vital ingredient for e-commerce in creating loyal and satisfied customers (Ratnasingham, 1998). Lee et al. (2007) find that 'trust expectations can also act as cognitive filtering devices by predisposing one to interpret the other's behavior as consistent with the original expectations' (p. 732). Thus, customers who trust online vendors will have expectations that are likely to be confirmed in terms of perceived satisfaction (Chiou \& Droge, 2006). This is further confirmed in a longitudinal study (Kim et al., 2009) in which trust is demonstrated to affect consumer e-loyalty through satisfaction in online environments. Hence, the following is hypothesised:

H3: Trust is positively related to satisfaction

\subsection{Intention to Reuse}

The literature suggests that one way of measuring e-commerce success is to ensure that online customers keep using a particular website and make purchases from it without changing to another retailer, which is also termed 'e-loyalty' (Wang, 2008). Usage intentions serve as a reasonable proxy for actual usage behaviour in marketing studies (Jang \& Namkung, 2009; Rose et al., 2012); hence, the terms 'continued intention to use', 'intention to reuse or return', and 'repeat purchase' all have connotations similar to 'e-loyalty' (Chen et al., 2015). Given the significance of customer loyalty for e-retailers, this study takes 
'intention to reuse' as the key outcome variable, as it signifies online customer loyalty and repurchase intentions (Rose et al., 2012). In particular, intention to reuse represents the intention of online customers to use the online retailer's website again (Castaneda et al., 2007).

\subsubsection{Trust and Intention to Reuse}

Highlighting the significance of trust for e-commerce, Reichheld and Schefter (2000, p. 107) remark that 'Price does not rule the Web; trust does', as the research finds that trust, not price, to be the most important factor for customers in deciding to consolidate their purchases with one e-retailer. Trust is a crucial aspect of e-commerce because of the inherent risks involved in online transactions (Pavlou \& Gefen, 2005). As online transactions take place across large geographical distances with no face-to-face personal interactions, buyers have limited control over e-retailers and their behaviours and are often concerned that the eretailers may not adhere to their transactional obligations. Hence, trust is more important for customers in online as opposed to offline transactions (Reichheld \& Schefter, 2000). At high levels of trust, a customer may not be highly concerned about any undesirable future behaviour by the e-retailer (Gefen et al., 2003), as a high level of trust is likely to increase the customer's willingness to accept vulnerability by forming an intention to purchase (Kim et al., 2009). The online literature is replete with studies that establish trust as an important determinant of the customers' intentions to reuse/e-loyalty (e.g. Chen et al., 2015; Jin et al., 2008; Kim et al., 2009; Rose et al., 2012). Accordingly, the following is hypothesised:

H4: Trust positively influences intention to reuse

\subsubsection{Satisfaction and Intention to Reuse}


Overall customer satisfaction is an 'affective' attitude formed in terms of customers' feelings of pleasure or disappointment resulting from a mental comparison of their perception and expectation levels of a product/service performance (Chiou \& Droge, 2006). As consumer satisfaction is the result of post-purchase evaluation and comparison, it is likely to influence intention to transact in the future (Oliver, 1981). Bhattacherjee (2001) finds a positive correlation between the intention to continue usage and satisfaction. Satisfied customers tend to engage in a higher usage of service (Bolton \& Lemon, 1999) and are often eager to recommend the product or service to others (Zeithaml et al., 1996), and thus possess stronger repurchase intentions (Rose et al., 2012) than those who are not satisfied. The online literature indicates that customers who are satisfied with the e-retailer are more likely to conduct further transactions through that e-retailer's website (Chen et al., 2015; Kim et al., 2009; Rose et al., 2012). Hence, the following is hypothesised:

H5: Satisfaction positively influences intention to reuse

\subsection{Structural Assurance (SA)}

Structural assurance refers to the degree to which consumers believe that institutional structures and mechanisms 'like guarantees, regulations, promises, legal recourse, or other procedures' (McKnight et al., 2002, p. 339) exist to promote the success of online transactions. Credit card guarantees, escrow services (like PayPal), 'seals of approval' (provided by independent accreditation authorities validating an e-vendor), secure electronic transaction (SET) infrastructure providing transaction protections (such as password protection) and e-vendor-specific guarantees such as product return/exchange policies, and cash-on-delivery are key examples of SA in the online context (Pavlou \& Gefen, 2005; Sha, 2009). Such institutional structures are essential, as they provide 'internet security guards' 
(Grabner-Kräuter, 2010) that protect customers against loss of privacy, identity, or money (McKnight et al., 2002) and make online transactions secure and trustworthy.

The institutional trust theory (Shapiro, 1987; Zucker, 1986) proposes that institutional structures and mechanisms can foster the growth of trust and cooperation between two parties, especially when both are unknown to each other, by establishing a certain degree of order that helps to reduce the complexity embedded in the external environment to a tolerable level (Sha, 2009). Thus, particularly in a context where some PCV is inevitable (Rousseau, 1995) such as in online buyer-seller relationships (Pavlou \& Gefen, 2005), SA as an institution-based trust mechanism not only helps to build consumers' trust but also diminishes their perceived risk with online transactions (Hogreve \& Gremler, 2009; Pavlou \& Gefen, 2005), thereby facilitating their satisfaction (Lee et al., 2007). Based on institutional trust theory (Shapiro, 1987; Zucker, 1986) and building on the seminal work of Mayer et al. (1995) and subsequent recent literature (Gefen \& Pavlou, 2012), this study examines SA as a moderator in the effects of PCV on trust and satisfaction.

\subsubsection{SA as Moderator}

Extant research suggests that SA plays an important role in positively influencing consumers' beliefs and intentions because a high level of SA increases the company's overall reliability along with vendor as well as technology trustworthiness, which enhances consumers' feelings of security with the online environment (Grabner-Kräuter, 2010). As trusting relationships are contextually embedded (Granovetter, 1985), SA remains important despite the quality of experience one encounters (McKnight \& Chervany, 2005). Because SA is not based on personal interactions, research within the organizational context finds that lack of trust in the organization caused by interpersonal events can be offset if SA is high (Tan \& Thoen, 2002). Consequently, it is suggested that safeguards or 'safety nets' (Shapiro, 
1987) provided by SA may reduce the negative effects arising from deficiencies in the fulfilment of the psychological contract (McKnight \& Chervany, 2005). Extending this logic to online marketplaces, it can be assumed that, while PCV as a negative experience is likely to influence trust and satisfaction negatively, such deleterious effects are likely to be buffered by SA.

In uncertain environments like online markets, perception of the institutional context 'reflects the individual assessment of situational uncertainty in the marketplace' (Gefen \& Pavlou 2012, p. 941) and thus determines the level of vulnerability perceived by online buyers. In fact 'people rely on institutional structures to create appropriate conditions for transaction activity' (Gefen \& Pavlou, 2012, p. 941). Under conditions of high SA, PCV may be less threatening; online buyers are likely to feel less vulnerable concerning the situational uncertainty caused by PCV because high SA is likely to instil confidence among buyers by strengthening their belief that their transactions are guaranteed by the institutional structures governing the online market (Gefen \& Pavlou, 2012). Buyers are likely to be certain that sellers will be forced to act in a socially appropriate manner, as institutional structures would protect them from any tangible losses that might occur due to PCV (Gefen \& Pavlou, 2012). Thus, SA strengthens customers' beliefs about positive recovery expectancy (Gefen \& Pavlou, 2012; Mayer et al., 1995). Accordingly, the legal systems built to protect customers are likely to reduce any complexities in the online environment arising due to PCV to a tolerable level (Sha, 2009). In this context, research has also shown that security signs and logos on e-vendors' websites indicating the existence of security systems lessen the psychological burden of online customers (Gefen et al., 2003). Thus, SA is likely to buffer the negative effects of PCV on buyers' trust and satisfaction because high SA alleviates buyer vulnerability and situational uncertainty resulting from PCV (Gefen \& Pavlou, 2012). 
Conversely, when SA is low, buyers are likely to perceive the available protection from economic vulnerability as inadequate and ineffective (Gefen \& Pavlou, 2012). Lack of adequate guarantees and legal systems (low SA) is likely to accentuate the need for cognitive efforts from buyers to control and understand the PCV situation, thereby diminishing their cognitive evaluations of the performance resulting from the online transaction (Gefen et al., 2003). Thus, when SA is low, buyers perceive that institutional structures lack the ability to reduce the complexity or situational uncertainty caused by PCV (Gefen \& Pavlou, 2012). Consequently, the negative effects of PCV on buyers' trust and satisfaction are likely to be more damaging. Hence, the following hypotheses are proposed:

H6 a): Structural assurance moderates the negative effects of PCV on trust such that the negative effects will be lesser when SA is high rather than low

H6 b): Structural assurance moderates the negative effects of PCV on satisfaction such that the negative effects will be lesser when SA is high rather than low

\section{Methodology}

\subsection{Context and Sample}

This empirical study was conducted among undergraduate students in a prestigious technical university in south India. A total of 379 students participated. A student sample was considered to be appropriate for this study, as this age group (18-24 years) has the highest level of internet penetration in India and is more likely to purchase online (Nair, 2013). It is therefore reasonable to expect the student segment to be representative of the target population, making it appropriate to use a student sample (Compeau et al., 2012). Using college students as participants in studies concerning online behaviour is also deemed appropriate because they are familiar with online shopping environments and are not being 
asked to imagine an unrealistic context (McKnight et al., 2002; Smith et al., 2013). In fact, in the context of online behaviour, a student sample can indicate the direction in which the general population is moving, as it typically represents early adopters of an innovation like eretailing (Burda \& Tueteberg, 2014; Gallagher et al., 2001); this could be useful, especially for countries like India. Accordingly, the sample was restricted to students who had frequently purchased from e-retailers in the past 12 months and had experienced some form of PCV. All the respondents were asked to choose the e-retailer they had used most for online purchases from a list of 13 e-retailers selected for this study. Of the 379 students, 316 chose one of the most popular e-retailers in India; the remaining 63 chose an e-retailer from among the other 12 e-retailers in the list. Preliminary analysis of the sample profile and the average values of the main independent and dependent variable through a MANOVA procedure did not show any significant difference between those who chose the major retailer and those who chose the other retailers; it was, therefore, considered appropriate to collect data from all 379 students. Of the sample, $85 \%$ were males and $15 \%$ were females, all within the $17-23$ age group, with the median age being 20 . No respondents were dropped from the study after data cleaning, maintaining the final sample at 379.

\subsection{Measures}

Psychological contract violation was measured using the methodology adopted by Pavlou and Gefen (2005). First, we conducted focus group discussions with 10 users of selected e-retailers' websites to understand typical contract violation incidents. From these discussions, the following four themes emerged: 'delivery delay', 'different product quality', 'difficulty in complaining/claiming refund', and 'non-delivery of item'. These themes broadly overlapped with anecdotal evidence on the Indian e-commerce system published in the popular press (Hartley \& Walker, 2013; Pandey et al., 2015) as well as the PCV items used 
by Pavlou and Gefen (2005). Hence, four items describing PCV for the study's context were developed and used to measure PCV. The PCV scenarios appear in Appendix2. The items were scored on a five-point scale ranging from 'never in my experience' to 'on most occasions'. Following Pavlou and Gefen (2005), PCV was modelled as a formative construct. The remaining constructs in the study were measured as reflective constructs.

Structural assurance was measured using four items adopted from McKnight et al. (2002). Trust was measured using five items adapted from Harris and Goode (2004). Intention to reuse the retail website was measured using three items developed based on the scale used by Castaneda et al. (2007), and satisfaction was measured using three items from the scale in Jin et al. (2008). Appendix 1 lists the items used in the study.

\subsection{Common Method Bias}

The potential for the results to be distorted by common method bias (CMB) cannot be ruled out, as the constructs were measured from the same source (Podsakoff et al., 2003). However, this study uses one formative construct (PCV) and several reflective constructs in the same model. Podsakoff et al. (2003) argue that, in such a model, ex-ante procedural controls are more effective in controlling $\mathrm{CMB}$ than are post-hoc statistical controls. Following suggestions by Podsakoff et al. (2003) and Chang et al. (2010), ex-ante controls were applied. All respondents were assured of complete anonymity and confidentiality, and were informed that there were no right or wrong answers. Additionally, the main independent variable, PCV, was measured via a set of factual questions, which limited CMB (Chang et al., 2010).

Regarding post-hoc controls, we first conducted a single-factor confirmatory factor analysis for all the reflective constructs; the results showed unacceptable levels of fit with the total variance explained by the single factor being less than $25 \%$. Second, common latent factor analysis (Podsakoff et al., 2003) was conducted, where by all observed variables in the 
measurement model were loaded on a common method construct besides loading on their respective latent constructs. The resultant model showed that the variance attributable to the common method factor was less than $4 \%$. Third, we compared the standardized loadings for each observed variable in the original model (without a common latent factor) with the model including a common latent factor. Comparison of the standardized loadings showed very little difference, demonstrating that CMB is not a problem in this study (Podsakoff et al., 2003).

\section{Data analysis}

A partial least square (PLS) model implemented through the smartPLS software (Ringle et al., 2005) was used to conduct the analysis. The PLS model is the most appropriate method when mixing formative and reflective constructs in the same path model. The PLS model also allows the exploration of moderating relationships simultaneously along with the path model.

All the reflective constructs demonstrate adequate psychometric properties. The scale items are presented in Appendix1. The composite reliability (CR) and Cronbach's alpha values of all the constructs were above 0.70 , confirming internal consistency reliability. The Average Variance Extracted (AVE) values for all constructs were above 0.50, except for trust, which was marginal at 0.47 . However, the square root of all the AVE values was higher than the latent correlation values between any two constructs, establishing discriminant validity (Fornell \& Larcker, 1981). The latent correlations, reliabilities, and AVEs are shown in Table1. The heterotrait-monotrait ratio (HTMT ratio), as another indicator of discriminant validity, was also calculated and was found to be within the acceptable level (0.85) for all four reflective constructs (see Table 2). The SRMR ratio for the composite model was 0.052 , considered an indicator of good model fit (Hu \& Bentler, 1999). The literature does not suggest a great number of quantitative checks for assessing the validity of formative construct 
measurements (Diamantopoulos et al., 2008). One suggested quantitative check is the multicollinearity level reflected in the Variance Inflation Factor (VIF) (Pousttchi \& Goeke, 2011). The outer VIF values were all below 2.00, suggesting very low multicollinearity. The outer loadings of the four components of the PCV construct show that, while three of the items have a loading of more than 0.50 , one item has a loading of less than 0.10 and a standardized loading of less than 0.00 . However, the literature posits that, for formative constructs, conceptual reasoning carries more weight than statistical results when deciding whether to drop formative indicators (Diamantopoulos et al., 2008), as dropping an indicator could alter the conceptual domain of the construct (Jarvis et al., 2003). Hence, we retain the item, as all four items provide conceptual clarity to the PCV construct and have high levels of construct validity.

\section{[Insert Table 1 and Table 2 about here]}

The validity of the relationships proposed in the conceptual model is assessed using the bootstrapping procedure (Henseler et al., 2009). The original values of the path coefficients and the p-values are provided in Table 3 (also see Figure 2). Psychological contract violation is found to have a negative and significant relationship with both trust $(-0.218 ; \mathrm{p} \leq .01)$ and satisfaction $(-0.184 ; \mathrm{p} \leq .01)$, validating $\mathrm{H} 1$ and $\mathrm{H} 2$. Hypothesis 3 is also supported, as trust has a positive relationship with satisfaction $(0.326 ; \mathrm{p} \leq .01)$. The relationship between both trust and intention to reuse $(0.254 ; \mathrm{p} \leq .01)$ as well as satisfaction and intention to reuse $(0.219 ; \mathrm{p} \leq .01)$ are found to be positive and significant, thus validating hypotheses H4 and H5. The interaction between SA and PCV on trust is significant $(\mathrm{p}<.05)$, although the moderating effect on satisfaction is found to be marginal $(\mathrm{p}=.10)$. This supports H6a and marginally supports H6b, implying that, as perceived SA increases, the negative impact of PCV on trust as well as satisfaction diminishes- though the moderating role is more prominent in the PCV-trust relationship than in the PCV-satisfaction relationship. As 
empirical support for moderating relationships are generally very difficult to obtain (Podsakoff et al., 1995), even at $\mathrm{p} \leq .10$, empirical support for a moderating relationship may be quite important for theory building.

[Insert Figure 2 about here]

[Insert Table 3 about here]

The mediating roles of trust and satisfaction are assessed using the bootstrapping method developed by Preacher and Hayes (2008) and implemented through the PROCESS macro offered in Hayes (2013). Due to the proposed relationship between trust and satisfaction, as well as the mediating effects of satisfaction and trust on intention to reuse, we tested for serial mediation. The results of the mediation analysis with a bootstrap sample of 5,000 cases, with a 95\% CI, are shown in Table 4 (a and b).

[Insert Tables $4 \mathrm{a}$ and $4 \mathrm{~b}$ about here]

As the results indicate, the direct effect of PCV on intention to reuse is insignificant as $\mathrm{p}=0.90$ and the limits of the CI contain the value 0 . Thus, trust and satisfaction fully mediate the relationship between PCV and intention to reuse. As for indirect effects, the total indirect effect is significant, with the bootstrap CI limits not containing the value 0 . The three mediating effects - PCV-trust-intention to reuse, PCV-trust-satisfaction-intention to reuse, and PCV-satisfaction-intention to reuse - are all found to be significant, with the bootstrap $\mathrm{CI}$ of none of the mediating relationships containing the value 0 . Thus, our findings indicate a full mediation effect for the two mediating variables (trust and satisfaction) in the relationship between PCV and intention to reuse.

We also tested a competing model with the direction of the relationship from trust to satisfaction reversed. The R-square values did not show any major difference. We also calculated Stone and Geisser's Q2 values through a blindfolding procedure. We found that 
the average Q2 value was smaller for the competing model than for the original model $(0.178$ to 0.163 ). Hence, we conclude that the model we propose is empirically superior.

\section{Discussion, Limitations, Future Research, and Conclusion}

This is the first empirical study to seek a better understanding of the process through which PCV influences intention to reuse in an e-retailing context. Consistent with the $\mathrm{S}-\mathrm{O}-\mathrm{R}$ framework, this study demonstrates that PCV negatively influences customers' intention to reuse a retailer's website via the mediating mechanisms of trust and satisfaction. Whereas previous findings have been mixed - with some studies (Goles et al., 2009) demonstrating full mediation and others indicating the partial mediation (Pavlou \& Gefen, 2005) effects of trust in the PCV-reuse intentions relationship - this study finds that both trust and satisfaction fully mediate the effects of PCV on reuse intentions. Thus, both satisfaction and trust are crucial in online retailing (Jin et al., 2008; Rose et al., 2012). This is an important result that enhances our understanding of the mechanisms by which PCV affects the intentions to reuse of online customers, as no study has examined the impact of PCV by considering both trust and satisfaction in a single, parsimonious framework.

Moreover, our findings suggest that a part of the effect of trust, which demonstrates the greatest mediating effect overall, is also mediated through satisfaction in series. Thus, one of the mechanisms by which PCV may influence intention to reuse is through serial mediation, whereby PCV influences trust, which affects satisfaction, which, in turn, influences intention to reuse. This implies that trust also influences reuse intentions indirectly by influencing buyers' overall satisfaction and that the negative impact of PCV on satisfaction is also realised when PCV destroys buyers' trust. Thus, this study provides a crucial theoretical insight into why PCV may be detrimental to customers' intention to reuse an e-retailer's website. When customers experience PCV, it ruins their confidence in the e- 
retailer's ability to perform as expected and destroys their trust (Goles et al., 2009; Pavlou \& Gefen, 2005). Additionally, PCV also negatively influences their satisfaction. Our findings suggest that these two processes are related but also contribute independently to subsequent intention to reuse.

Another crucial result of the analysis is the significance of perceived SA in buffering the negative effects of PCV on both trust and satisfaction. This is an important finding, as prior research has generally found service recovery efforts by online retailers to be ineffective, which negatively affects important customer behaviours, particularly retention (Holloway \& Beatty, 2003). By demonstrating the significance of SA in online environments, our study fruitfully addresses calls in the e-retailing literature for identifying strategies that can weaken the potential negative impact of service failure(s) on customer loyalty within an e-tailing environment (Sousa \& Voss, 2009; Wang et al., 2011).

Although the e-retailing research has established the negative effects of PCV on trust (Goles et al., 2009; Pavlou \& Gefen, 2005), no previous study has investigated how the deleterious effects of PCV can be controlled or mitigated. Our findings demonstrate that SA plays a critical role in online environments. As indicated in Figure 3, buyers' trust continues to be consistently high irrespective of the PCV level under conditions of high SA. Thus, SA provides the 'safety nets' that help to safeguard buyers' confidence in the online vendor by mitigating buyer vulnerability and situational uncertainty arising due to PCV. Considering that trust crucially influences reuse intentions both directly and indirectly via satisfaction, our findings indicate that investment in SA is paramount for successful e-retailing, as it helps to protect trust from the deleterious effects of PCV and thus cannot be ignored.

Regarding satisfaction, the moderating effect of SA on the PCV-satisfaction relationship is found to be marginally significant. As India's regulatory structure may not be as robust and well-implemented as are those of developed countries, online customers in 
India who experience PCV may not perceive SA's role as extremely satisfying, which may explain the marginal moderating effect of SA on the PCV-satisfaction relationship. Moreover, although SA moderates the effects of PCV on satisfaction, it is effective only when PCV is low to moderate. As Figure 4 shows, satisfaction is highest when PCV is low and SA is high; when PCV is perceived to be high, even high SA fails to safeguard satisfaction from the damaging effects of PCV, possibly because high PCV exacerbates the buyer's need to expend additional cognitive effort in order to understand, monitor, and control the situation (Gefen et al., 2003). Given that Internet shopping is considered much riskier than traditional brick and mortar shopping (Laroche et al., 2005), high PCV situations are likely to substantially increase buyers' cognitive overheads. As satisfaction involves 'cognitive mechanisms rooted in expectations and its disconfirmation based on service performance in a specific episode' (Singh \& Sirdeshmukh, 2000, p. 159), high PCV diminishes buyers' overall satisfaction despite high SA. This is a crucial finding and provides useful insights into the moderating role of SA. While high SA safeguards customers' trust irrespective of PCV level, no amount of SA can protect customer satisfaction from eroding when PCV is high.

\section{[Insert Figure 3 and Figure 4 about here]}

From a managerial perspective, our study indicates that PCV can be deleterious to the success of e-retailing because it negatively affects both the trust and satisfaction of online buyers, which in turn influences their intentions to reuse the e-vendor's website. Our findings indicate that it is vital for online retailers to safeguard customers' trust at all costs. Trust not only influences buyers' intentions to reuse an e-vendor's service directly but also influences them indirectly by influencing their overall satisfaction. Our study thus demonstrates that investments in SA are paramount for preserving buyers' trust in the online retailer when PCV occurs. This is a crucial finding, especially for the e-retailing sector in emerging economies 
like India: on the one hand, e-retailers are competing intensely for too few customers; on the other, they are grappling with problems related to logistics and payment gateways that invariably lead to instances of PCV (Hartley \& Walker, 2013). Hence, e-retail companies should conceive strategies for improving SA as perceived by customers, so that customers who encounter isolated instances of PCV will not abandon e-retailers. Although SA plays a critical role in protecting buyers' trust from the deleterious effects of PCV, investments in SA should not be considered a panacea, as our findings indicate that its role in preserving buyer satisfaction is effective only when PCV is perceived as low to moderate. Thus, e-vendors should proactively limit the incidence and magnitude of PCV to the minimum. However, given that some PCV is inevitable in the e-retailing context, our study underscores the significance of SA and provides useful practical insights that should remind e-retailers to prioritise investments in building solid technical and legal safeguards.

Despite its important contributions, this study should be interpreted in light of its limitations. Since a convenience sampling methodology was used, the results may have limited external validity. Although convenience samples are considered suitable for testing theory (Richard \& Chebat, 2016; Smith et al., 2013), future studies could test the study framework in different contexts utilizing longitudinal research designs to improve the generalizability of the results. Moreover, the study was conducted among online shoppers in India. The literature indicates that customers in higher individualism or lower uncertainty-avoidance cultures (e.g. the US) tend to switch or complain more but also tend to be more trusting of others than are customers in collectivist cultures (Jin et al., 2008). As India is a collectivist society, this study could be replicated in different countries to explore if cultural differences influence the nature and strength of the relationships examined. A notable finding of the study is the significance of SA in buffering the deleterious impact of PCV. While SA significantly moderates the effects of PCV on trust, it demonstrates marginal moderating effects on the PCV-satisfaction 
relationship. Hence, the moderating role of SA needs further investigation, as it may be possible to obtain stronger effects in other developed countries where institutional structures are more robust and better implemented.

As the research suggests that different forms of SA could have different effects (Sha, 2009), in future it would be useful to study different types of SA separately to determine the true nature of its moderating influence. Future studies could probe beyond SA and examine other moderating mechanisms such as technology readiness, level of social presence, and retailer reputation, which may influence how PCV affects customer attitudes and behaviour. Given the equivocal claims in the retailing literature about perceived risk - with some researchers considering it a major factor (Chang \& Chen, 2008; Jarvenpaa et al., 2000) and others considering it minor (Gefen, 2000) - future studies could also include perceived risk along with trust and satisfaction to further understand the relative influence of different mediating mechanisms by which PCV influences customer behaviour. Other outcome variables, such as word of mouth, customer rage, or actual transactional data could be incorporated to determine the impact of PCV. Another avenue for future research is examining new technologies. With the rapid expansion in mobile commerce usage over the past few years (Chong, 2013), similar issues could be explored in the context of mobile commerce. As psychological contracts are reciprocal, PCV and related issues could also be studied from the seller's perspective.

Overall, this study makes a significant contribution to the e-retailing literature by providing the first empirical investigation of the mediating and moderating mechanisms underpinning the relationship between PCV and intention to reuse. Our study is likely to stimulate future research on the nature and influence of PCV in e-retail environments and, more importantly, how its deleterious effects can be mitigated. 


\section{References}

Balachandar, G. (2015), New age Indians to spur retail market to $\$ 2.1$ trillion in 2025, The Hindu, available at: http://www.thehindu.com/business/Economy/new-age-indians-tospur-retail-market-to-12-trillion-by-2025/article7211132.ece accessed on 03/03/2016.

Bal, M.P., De Lange, A.H., Jansen P.G.W., \& Van der Velde, M.E.G. (2008), Psychological contract breach and job attitudes: A meta-analysis of age as a moderator, Journal of Vocational Behavior, 72, 143-158. doi:10.1016/j.jvb.2007.10.005.

Bagozzi, R.P. (1986), Principle of Marketing Management, Chicago: SRA.

Bagozzi, R.P. (1992), The self-regulation of attitudes, intentions, and behavior, Social Psychology Quarterly, 55(2), 178-204.

Bagozzi, R., Gopinath, M., \& Nyer, P. (1999), The role of emotions in marketing, Journal of the Academy of Marketing Science, 27(2), 184-206. doi: 10.1177/0092070399272005.

Balasubramanian, S., Konana, P., \& Menon, N.M. (2003), Customer satisfaction in virtual environments: A study of online investing, Management Science, INFORMS, 49(7), 871-889. http://www.jstor.org/stable/4133963

Bhattacherjee, A. (2001), An empirical analysis of the antecedents of electronic commerce service continuance, Decision Support Systems, 32(2), 201-214. doi: 10.1016/S01679236(01)00111-7.

Bitner, M.J., Booms, B.M., \& Tetreault, M.S. (1990), The service encounter: Diagnosing favorable and unfavorable incidents, Journal of Marketing, 54, Jan., 71-85. doi: $10.2307 / 1252174$

Bolton, R.N., \& Lemon, K.N. (1999), A dynamic model of customers' usage of services: Usage as an antecedent and consequence of satisfaction, Journal of Marketing Research, 36(2) 171-186. doi: 10.2307/3152091. 
Brady, M.K., Cronin, J.J., Jr., Fox, G.L., \& Roehm, M.L. (2008), Strategies to offset performance failures: The role of brand equity, Journal of Retailing, 84(2) 151-164. doi:10.1016/j.jretai.2008.04.002.

Burda, D., \& Teuteberg, F. (2014), The role of trust and risk perceptions in cloud archivingResults from an empirical study, Journal of High Technology Management Research, 25(2), 172-187. doi: 10.1016/j.hitech.2014.07.008.

Castaneda, J.A., Francisco, M., \& Luque, T. (2007), Web Acceptance Model (WAM): Moderating effects of user experience, Information \& Management, 44(4), 384-396. doi: 10.1016/j.im.2007.02.003.

Chang, H.H., \& Chen, S.W. (2008), The impact of online store environment cues on purchase intention: Trust and perceived risk as a mediator, Online Information Review, 32(6), 818-841. doi: 10.1108/14684520810923953

Chang, S.J., Witteloostuijn, A., \& Eden, L. (2010), From the editors: common method variance in international business research, Journal of International Business Studies, 41(2), 178-184. http://EconPapers.repec.org/RePEc:pal:jintbs:v:41:y:2010:i:2:p:178184.

Chen, J.V., Yen, D.C., Pornpriphet, W., \& Widjaja, A.E. (2015), E-commerce web site loyalty: A cross cultural comparison, Information Systems Frontiers, 17(6), 12831299. doi: 10.1108/CCM-10-2013-0150.

Chiou, J-S \& Droge, C. (2006), Service quality, trust, specific asset investment, and expertise: Direct and indirect effects in a satisfaction-loyalty framework, Journal of the Academy of Marketing Science, 34(4), 613-627. doi: 10.1177/0092070306286934.

Chong, A.Y.L. (2013), Mobile commerce usage activities: The roles of demographic and motivation variables, Technological Forecasting and Social Change, 80(7), 1350-1359. doi: http://dx.doi.org/10.1016/j.techfore.2012.12.011 
Compeau, D., Marcolin, B., Kelly, H., \& Higgins, C. (2012), Research commentarygeneralizability of information systems research using student subjects-a reflection on our practices and recommendations for future research. Information Systems Research, 23(4), 1093-1109.

Diamantopoulos, A., Riefler, P., \& Roth, K.P. (2008), Advancing formative measurement models, Journal of Business Research, 61(12), 1203-1218. doi:10.1016/j.jbusres.2008.01.009.

Eroglu, S.A., Machleit, K.A., \& Davis, L.M. (2001), Atmospheric qualities of online retailing: A conceptual model and implications, Journal of Business Research, 54(2), 177-184. doi:10.1016/S0148-2963(99)00087-9.

Euromonitor (2016), "Internet retailing in India", available at: http://www.euromonitor.com/internet-retailing-in-india/report accessed on 3/3/2016 Fang, Y.H., \& Chiu, C.M. (2014), Exploring online double deviation effect from psychological contract violation, emotion, and power perspectives, Pacific Asia Journal of the Association for Information Systems, 6(1), 39-65.

Fornell, C., \& Larker, D.F. (1981), Evaluating structural equation models with unobservable variables and measurement error, Journal of Marketing Research, 18(1) 39-50. doi: $10.2307 / 3151312$.

Fishbein, M., \& Ajzen, I. (1975), Beliefs, Intention and Behavior, fifth ed. Addison- Wesley, Reading, MA.

Gallagher, K., Parsons, J., \& Foster K.D. (2001), A tale of two studies: Replication of advertising effectiveness and content evaluation in print and in the web, Journal of Advertising Research, 41(4), 71-82.

Gefen, D. (2000), E-commerce: The role of familiarity and trust, Omega, 28 (5), 725-737. 
Gefen, D., \& Pavlou, P.A. (2012), The boundaries of trust and risk: The quadratic moderating role of institutional structures, Information Systems Research, 23(3), 940-959. doi: $10.2307 / 23274654$.

Gefen D., Karahanna, E., \& Straub, D. (2003), Trust and TAM in online shopping: An integrated model, MIS Quarterly, 27, 51-90.

Goles, T., Lee, S., Rao, S.V., \& Warren, J. (2009), Trust violation in electronic commerce: Customer concerns and reactions, Journal of Computer Information Systems, 49(4) (summer), 1-9.

Grabner-Kräuter, S. (2010), Web 2.0 social networks: The role of trust, Journal of Business Ethics, 90, 505-522. doi: 10.1007/s10551-010-0603-1.

Granovetter, M. (1985), Economic action and social structure: The problem of embeddedness, American Journal of Sociology, 91(3), 481-510. http://www.jstor.org/stable/2780199.

Harris, L.C., \& Goode, M.M.H. (2004), The four levels of loyalty and the pivotal role of trust: a study of online service dynamics, Journal of Retailing, 80(2), 139-158. doi:10.1016/j.jretai.2004.04.002.

Harris, L.C., \& Goode, M.M.H. (2010), Online servicescapes, trust, and purchase intentions, Journal of Services Marketing, 24(3), 230-243. http://dx.doi.org/10.1108/08876041011040631.

Hartley, M., \& Walker, C. (2013), The growing pains of Indian e-commerce: What you need to know, Forbes.com available at: http://www.forbes.com/sites/morganhartley/2013/01/24/the-growing-pains-of-indian-ecommerce-what-you-need-to-know/\#216fd105126caccessed on 3/3/2016.

Hayes, A.F. (2013), Introduction to mediation, moderation, and conditional process analysis: A regression-based approach. Guilford Press. 
Henseler, J., Ringle, C.M., \& Sinkovics, R.R. (2009), 'The use of partial least squares path modeling in international marketing,' in Advances in International Marketing, 20, Rudolf R. Sinkovics and Pervez N. Ghauri, eds. Bingley: Emerald 277-320. eISBN:978-1-84855-469-6.

Hill, J.A., Eckerd, S., Wilson, D., \& Greer, B. (2009), The effect of unethical behavior on trust in a buyer-supplier relationship: The mediating role of psychological contract violation, Journal of Operations Management, 27(4), 281-293doi: 10.1016/j.jom.2008.10.002.

Hogreve, J., \& Gremler, D.D. (2009), Twenty years of service guarantee research. A synthesis, Journal of Service Research, 11(4), 322-343. doi: 10.1177/1094670508329225.

Holloway, B.B., \& Beatty, S.E. (2003), Service failure in online retailing: A recovery opportunity, Journal of Service Research, 6(1), 92-105. doi:10.1177/1094670503254288.

Hu, L., \& Bentler, P.M. (1999), Cut-off criteria for fit indexes in covariance structure analysis: Conventional criteria versus new alternatives, Structural Equation Modeling, 6, 1-55.doi: 10.1080/10705519909540118.

Jarvenpaa, S., Tractinsky, N., \&Vitale, M. (2000), Consumer trust in an internet store, Information Technology and Management, 1(12), 45-71.

Jarvis, C.B., MacKenzie, S.B., \& Podsakoff, P.M. (2003), A critical review of construct indicators and measurement model misspecification in marketing and consumer research, Journal of Consumer Research, 30,199-218. doi: 10.1086/376806.

Jang, S.S., \& Namkung, Y. (2009), Perceived quality, emotions, and behavioral intentions: Application of an extended Mehrabian-Russell model to restaurants, Journal of Business Research, 62(4), 451-460. doi:10.1016/j.jbusres.2008.01.038. 
Jin, B., Yong Park, J., \& Kim, J. (2008), Cross-cultural examination of the relationships among firm reputation, e-satisfaction, e-trust, and e-loyalty, International Marketing Review,25(3), 324-337.doi: 10.1108/02651330810877243.

Joireman, J., Yany, G., Berna, D., \& Tripp, T.M. (2013), When do customers offer firms a "second chance" following a double deviation? The impact of inferred firm motives on customer revenge and reconciliation, Journal of Retailing, 89 (3), 315-337. doi: 10.1016.j.jretai.2013.03.002.

Kawaf, F., \& Tagg, S. (2012), Online shopping environments in fashion shopping: An SOR based review, The Marketing Review, 12(2), 161-180.

Kim, H., \& Lennon, S.J. (2010), E-atmosphere, emotional, cognitive, and behavioral responses, Journal of Fashion Marketing and Management, 14(3), 412-428. doi: 10.1108/13612021011061861.

Kim, D.J., Ferrin, D.L., \& Rao, H.R. (2009), Trust and satisfaction, two stepping stones for successful e-commerce relationships: A longitudinal exploration, Information Systems Research, 20(2), 237-257.

Kingshott, R.P.J., \& Pecotich, A. (2007), The impact of psychological contract on trust and commitment in supplier-distributors relationship, European Journal of Marketing, 41(910), 1053-1072. doi: 10.1108/03090560710773345.

Laroche, M., Yang, Z., McDougall, G.H.G., \& Bergeron, J. (2005), Internet versus bricksand-mortar retailers: An investigation into intangibility and its consequences, Journal of Retailing, 81(4), 251-267. doi: 10.1016/j.jretai.2004.11.002.

Lee, K.C., Kang, I., \& McKnight, D.H. (2007), Transfer from offline trust to key online perceptions: an empirical study, IEEE Transactions on Engineering Management, 54(4), 729-741. 
Lövblad, M., Akmal, S.H., \& Lönnstedt, L. (2012), Affective commitment in industrial customer-supplier relations: a psychological contract approach, Journal of Business \& Industrial Marketing, 27(4), 275 - 285. doi: 10.1108/08858621211221652.

Mayer, R.C., Davis, J.H., \& Schoorman, F.D. (1995), An integrative model of organizational trust, Academy of Management Review, 20(3), 709-734. http://www.jstor.org/stable/258792

McCollough, M.A., Berry, L.L., \& Yadav, M.S. (2000), An empirical investigation of customer satisfaction after service failure and recovery, Journal of Service Research, 3(2), 121-137.

McKnight, D.H., Choudhury, V., \& Kacmar, C.J. (2002), Developing and validating trust measures for e-commerce: An integrative typology, Information Systems Research, 13(3), 334-359.

McKnight, D.H., \& Chervany, N.L. (2005), What builds system troubleshooter trust the best: Experiential or non-experiential factors, Information Resources Management Journal, 18(3), 2-49.

Mehrabian, A., \& Russell, J. A. (1974), An approach to environmental psychology. The MIT Press.

Meuter, M., Ostrom, A., Roundtree, R., \& Bitner, M. (2000), Self-service technologies: understanding customer satisfaction with technology-based service encounters, Journal of Marketing, 64(3),50-64.doi: 10.1509/jmkg.64.3.50.18024

Namkung, Y., \& Jang, S.C. (2010), Effects of perceived service fairness on emotions, and behavioral intentions in restaurants, European Journal of Marketing, 44(9/10), 1233 1259. doi: $10.1108 / 03090561011062826$.

Niehoff, B.P., \& Paul, R.J. (2001), The just workplace: Developing and maintaining effective psychological contracts, Review of Business, 22, 5-8. 
Nair, P. (2013), Internet users in India to triple by 2016: Digital hold on buying seen rising as $40 \%$ of net users rely go online for product research and price comparison before buying, Business Standard, available at: http://www.businessstandard.com/article/technology/internet-users-in-india-to-tripleby-2016-113042500185_1.html accessed on 25/06/2014.

Oliver, R.L. (1981), Measurement and evaluation of satisfaction processes in retail settings, Journal of Retailing, 57(3), 25-48.

Palmer, A., Beggs, R., \& Keown-McMullan, C. (2000), Equity and repurchase intention following service failure, Journal of Services Marketing, 14(6), 513-528. Doi: $10.1108 / 08876040010347624$.

Pandey, S., Chawla, D., \& Venkatesh, U. (2015), Online shopper segmentation based on lifestyles: An exploratory study in India, Journal of Internet Commerce, 14(1), 21-41. doi: 10.1080/15332861.2015.1006516.

Pavlou, P.A., \& Gefen, D. (2004), Building effective online marketplaces with institutionbased trust, Information Systems Research, 15(1), 37-59. doi: 10.1287/isre.1040.0015.

Pavlou, P.A., \& Gefen, D. (2005), Psychological contract violation in online marketplaces: Antecedents, consequences, and moderating role, Information Systems Research, 16(4), $372-399$.

Podsakoff, P.M., MacKenzie, S.B., Ahearne, M., \& Bommer, W.H. (1995), Searching for a needle in a haystack: Trying to identify the illusive moderators of leadership behaviors, Journal of Management, 21(3), 422-470. doi: 10.1177/014920639502100303.

Podsakoff, P.M., MacKenzie, S.B., Podsakoff, N.P., \& Lee, J.Y. (2003), Common method biases in behavioral research: A critical review of the literature and recommendations, Journal of Applied Psychology, 88(5), 879-903. doi: 10.1037/0021-9010.88.5.879. 
Pousttchi, K., \& Goeke, L. (2011), Determinants of customer acceptance for mobile data services: an empirical analysis with formative constructs, International Journal of Electronic Business, 9(1-2), 26-43. doi:10.1504/IJEB.2011.040354.

Preacher, K.J., \& Hayes, A.F. (2008), Asymptotic and resampling strategies for assessing and comparing indirect effects in multiple mediator models, Behavior Research Methods, 40(3), 879-891. doi: 10.3758/BRM.40.3.879.

Ratnasingham, P. (1998), The importance of trust in electronic commerce, Internet Research: Electronic Networking Applications and Policy, 8(4), 131-321.doi: $10.1108 / 10662249810231050$.

Reichheld, F.F., \& Schefter, P. (2000), E-Loyalty: Your secret weapon on the web, Harvard Business Review, 78(4), 105-113.

Richard, M.O., \& Chebat, J.C. (2016), Modeling online consumer behavior: Preeminence of emotions and moderating influences of need for cognition and optimal stimulation level, Journal of Business Research, 69(2), 541-553. doi:10.1016/j.jbusres.2015.05.010.

Ringle, C.M., Sven Wende, \& Will, A. (2005), SmartPLS 2.0 (beta),www.smartpls.de Robinson, S.L., \& Rousseau, D.M. (1994), Violating the psychological contract: Not the exception but the norm, Journal of Organizational Behavior, 15(3), 245-259. doi: 10.1002/job.4030150306.

Rose, S., Clark, M., Samouel, P., \& Hair, N. (2012), Online customer experience in eretailing: an empirical model of antecedents and outcomes, Journal of Retailing, 88(2), 308-322.doi:10.1016/j.jretai.2012.03.001.

Rousseau, D.M. (1995), Psychological contracts in organizations. Understanding written and unwritten agreements, Thousand Oaks, CA: Sage. 
Rousseau, D.M., \& Tijoriwala, S.A. (1998), Assessing psychological contracts: issues, alternatives, and measures, Journal of Organizational Behavior, 19(1), 679-695. doi: 10.1002/(SICI)1099-1379(1998)19:1+<679::AID-JOB971>3.0.CO;2-N.

Rousseau, D.M., Sitkin, S.B., Burt, R.S., \& Camerer, C. (1998), Not so different after all: a cross-discipline view of trust, Academy of Management Journal, 23(3), 393-404.

Sajtos, L., Brodie, R.J., \& Whittome, J. (2010), Impact of service failure: The protective layer of customer relationships, Journal of Service Research, 13(2), 216-229.doi: $10.1177 / 1094670510365357$

Sels, L., Janssens, M., \& Van den Brande, I. (2004), Assessing the nature of psychological contracts: A validation of six dimensions, Journal of Organisational Behavior, 25, 461488.doi: 10.1002/job.250

Sha, W. (2009), Types of structural assurance: SA and their relationships with trusting intentions in business-to-consumer e-commerce, Electronic Markets, 19(1), 43-54. doi:10.1007/s12525-008-0001-z.

Shapiro, S.P. (1987), The social control of impersonal trust, American Journal of Sociology, 93(3), 623-658. http:/www.jstor.org/stable/2780293.

Singh, J., \& Sirdeshmukh, D. (2000), Agency and trust mechanisms in consumer satisfaction and loyalty judgments, Journal of the Academy of Marketing Science, 28(1), 150-168. doi: $10.1177 / 0092070300281014$.

Smith, A.K., \& Bolton, R.N. (1998), An experimental investigation of service failure and recovery: Paradox or peril? Journal of Service Research, 1 (1), 65-81.doi: $10.1177 / 109467059800100106$

Smith, A.K., Bolton, R.N., \& Wagner, J. (1999), A model of customer satisfaction with service encounters involving failure and recovery, Journal of Marketing Research, 36 (August), 356-72. doi: 10.2307/3152082. 
Smith, R., Deitz, G., Royne, M.B., Hansen, J.D., Grünhagen, M., \&Witte, C. (2013), Crosscultural examination of online shopping behavior: A comparison of Norway, Germany, and the United States, Journal of Business Research, 66, 328-335. doi:10.1016/j.jbusres.2011.08.013.

Sousa, R., \& Voss, C.A. (2009), The effects of service failures and recovery on customer loyalty in e-services: An empirical investigation, International Journal of Operations \& Production Management, 29(8), 834-864. doi: 10.1108/01443570910977715.

Surachartkumtonkun, J., Patterson, P. G., \& McColl-Kennedy, J. R. (2013), Customer rage back-story: linking needs-based cognitive appraisal to service failure type, Journal of Retailing, 89(1), 72-87.

Tan, Y.H., \& Thoen, W. (2002), Formal aspects of a generic model of trust for electronic commerce, Decision Support Systems, 33(3), 233-246. doi:10.1016/S01679236(02)00014-3.

Tax, S.S., \& Brown, S.W. (1998), Recovering and learning from service failure, MIT Sloan Management Review, 40(1), 75.

Tax, S.S., Brown, S.W., \& Chandrashekaran, M. (1998), Customer evaluations of service complaint experiences: Implications for relationship marketing, Journal of Marketing, 62(2), 60-76. doi: 10.2307/1252161.

Theotokis, A., Pramatari, K., \& Tsiros, M. (2012), Effects of expiration date-based pricing on brand image perceptions, Journal of Retailing, 88(1), 72-87. doi: 10.1016/j.jretai.2011.06.003.

Tokman, M., Davis, L.M., \& Lemon, K.N. (2007), The WOW factor: Creating value through win-back offers to reacquire lost customers, Journal of Retailing, 83(1), 47-64. doi:10.1016/j.jretai.2006.10.005. 
Vieira, V.A. (2013), Stimuli-organism-response framework: A meta-analytic review in the store environment, Journal of Business Research, 66(9), 1420-1426.

Verhoef, P.C., Lemon, K.N., Parasuraman, A., Roggeveen, A., Tsiros, M., \& Schlesinger, L. A. (2009), Customer experience creation: Determinants, dynamics and management strategies, Journal of Retailing, 85(1), 31-41.doi: 10.1016/j.jretai.2008.11.001.

Verma, S. (2015), India on course to overtake US next month in Internet User Base, Livemint.com available at: http://www.livemint.com/Politics/9Vipq3XmcfQuhJRMBleuwL/Indias-Internet-usersset-to-increase-49-to-402-million-by.html accessed on 03/03/2016.

Wang, Y.S. (2008), Assessing e-commerce system success: A respecification and validation of the DeLone and McLean model of IS success, Information System Journal, 18(5), 529-557. doi: 10.1111/j.1365-2575.2007.00268.x.

Wang, S., \& Huff, L.C. (2007), Explaining buyers' responses to sellers' violation of trust, European Journal of Marketing, 41(9/10), 1033-1052. doi: 10.1108/03090560710773336.

Wang, Y.J., Hernandez, M.D., \& Minor, M.S. (2010), Web aesthetics effects on perceived online service quality and satisfaction in an e-tail environment: The moderating role of purchase task, Journal of Business Research, 63(9-10), 935-942. doi: 10.1016/j.jbusres.2009.01.016.

Wang, Y.S., Wu, S.C., Lin, H.H., \& Wang, Y.Y. (2011), The relationship of service failure severity, service recovery justice and perceived switching costs with customer loyalty in the context of e-tailing, International Journal of Information Management, 31(4), 350-359.doi: 10.1016/j.ijinfomgt.2010.09.001 
Weun, S., Beatty, S.E., \& Jones, M.A. (2004), The impact of service failure severity on service recovery evaluations and post-recovery relationships, Journal of Services Marketing, 18(2), 133-146.doi: 10.1108/08876040410528737

Xiao, B., \& Benbasat, I. (2011), Product-related deception in e-commerce: a theoretical perspective, MIS Quarterly, 35(1), 169-196.

Yi, Y., \& Gong, T. (2009), An integrated model of customer social exchange relationship: the moderating role of customer experience. The Service Industries Journal, 29(11), 15131528. doi: 10.1080/02642060902793474.

Zeithaml, V.A., Berry, L.L., \& Parasuraman, A. (1996), The behavioral consequences of service quality, Journal of Marketing, 60(2), 31-46. doi: 10.2307/1251929.

Zhao, H.A.O., Wayne, S.J., Glibkowski, B.C., \& Bravo, J. (2007), The impact of psychological contract breach on work-related outcomes: a meta-analysis, Personnel Psychology, 60(3), 647-680.doi: 10.1111/j.1744-6570.2007.00087.x.

Zucker, L.G. (1986), Production of Trust: Institutional Source of Economic Structure, 18401920, Research in Organizational Behavior, 8, 53-111. 
Table 1

Discriminant validity of constructs

\begin{tabular}{|l|r|l|l|l|l|l|r|}
\hline & REUSE & SAT & SA & TRUST & (AVE) & $\begin{array}{l}\text { Composite } \\
\text { Reliability }\end{array}$ & $\begin{array}{l}\text { Cronbach's } \\
\text { Alpha }\end{array}$ \\
\hline REUSE & $\mathbf{0 . 7 9 8}$ & & & & 0.637 & 0.840 & 0.718 \\
\hline SAT & 0.318 & $\mathbf{0 . 7 9 7}$ & & & 0.636 & 0.839 & 0.719 \\
\hline SA & 0.176 & 0.247 & $\mathbf{0 . 8 1 8}$ & & 0.669 & 0.890 & 0.836 \\
\hline TRUST & 0.339 & 0.391 & 0.237 & $\mathbf{0 . 6 8 5}$ & 0.469 & 0.805 & 0.701 \\
\hline
\end{tabular}

*The off diagonal elements are the inter-construct correlations. The diagonal values are square root of the Average Variance Extracted (AVE).

Abbreviations: REUSE = Intention to reuse; $\mathrm{SAT}=$ Satisfaction; $\mathrm{SA}=$ Structural Assurance

Table 2

Heterotrait-Monotrait ratio (HTMT ratio)

\begin{tabular}{|l|r|r|l|}
\hline & $\begin{array}{l}\text { INTENTION } \\
\text { TO REUSE }\end{array}$ & SATISFACTION & $\begin{array}{l}\text { STRUCTURAL } \\
\text { ASSURANCE }\end{array}$ \\
\hline INTENTION TO REUSE & & & \\
\hline SATISFACTION & 0.416 & & \\
\hline STRUCTURAL ASSURANCE & 0.214 & 0.317 & \\
\hline TRUST & 0.446 & 0.504 & 0.319 \\
\hline
\end{tabular}


Table 3

Path Analysis results

\begin{tabular}{|l|l|l|l|}
\hline & $\begin{array}{l}\text { Std. } \\
\text { estimate }\end{array}$ & P Values & Hypotheses \\
\hline PCV -> TRUST & $-0.218^{* * *}$ & 0.00 & $\mathrm{H} 1(\mathrm{~S})$ \\
\hline PCV -> SATISFACTION & $-0.184^{* * *}$ & 0.00 & $\mathrm{H} 2(\mathrm{~S})$ \\
\hline TRUST -> SATISFACTION & $0.326^{* * *}$ & 0.00 & $\mathrm{H} 3(\mathrm{~S})$ \\
\hline TRUST -> INTENTION TO REUSE & $0.254^{* * *}$ & 0.00 & $\mathrm{H} 4(\mathrm{~S})$ \\
\hline SATISFACTION -> INTENTION TO REUSE & $0.219^{* * *}$ & 0.00 & $\mathrm{H} 5(\mathrm{~S})$ \\
\hline SA -> SATISFACTION & $0.176^{* * *}$ & 0.00 & \\
\hline SA -> TRUST & $0.219^{* * *}$ & 0.00 & \\
\hline SA*PCV -> TRUST & $0.101^{* *}$ & 0.04 & $\mathrm{H6a}(\mathrm{S})$ \\
\hline SA*PCV -> SATISFACTION & $-0.106^{*}$ & 0.10 & $\mathrm{H} 6 \mathrm{~b}(\mathrm{MS})$ \\
\hline $\begin{array}{l}\text { R-square values } \\
\text { Intention to Reuse: } 0.156\end{array}$ & & & \\
$\begin{array}{l}\text { Trust } \\
\text { Satisfaction } 0.127\end{array}$ & & & \\
\hline
\end{tabular}

$* * * \mathrm{p} \leq 0.01, * * \mathrm{p} \leq 0.05, * \mathrm{p} \leq 0.10$

Abbreviations: $\mathrm{S}=$ Supported; $\mathrm{MS}=$ Marginally Supported; SA= Structural Assurance; $\mathrm{PCV}=$ Psychological Contract Violation 
Table 4

Serial Mediation Analysis

Table 4a

\begin{tabular}{|l|l|l|l|l|l|l|}
\hline & Effect & SE & $\mathrm{t}$ & $\mathrm{p}$ & Lower CI & Upper CI \\
\hline $\begin{array}{l}\text { Direct effect of PCV on } \\
\text { intention to reuse }\end{array}$ & -.0060 & .0530 & -.1130 & .9101 & -.1102 & .0982 \\
\hline
\end{tabular}

Table 4b

\begin{tabular}{|l|l|l|l|l|}
\hline & Effect & Boot SE & Boot LLCI & BootULCI \\
\hline Total Indirect Effect & -0.0827 & 0.0234 & -0.1345 & -0.0419 \\
\hline PCV to Trust to intention to reuse & -0.0408 & 0.0181 & -0.0884 & -0.0136 \\
\hline PCV to Trust to satisfaction to intention to reuse & -0.0111 & 0.0058 & -0.0273 & -0.0034 \\
\hline PCV to satisfaction to intention to reuse & -0.0308 & 0.0153 & -0.0696 & -0.0073 \\
\hline
\end{tabular}


Figure.1

Conceptual Model

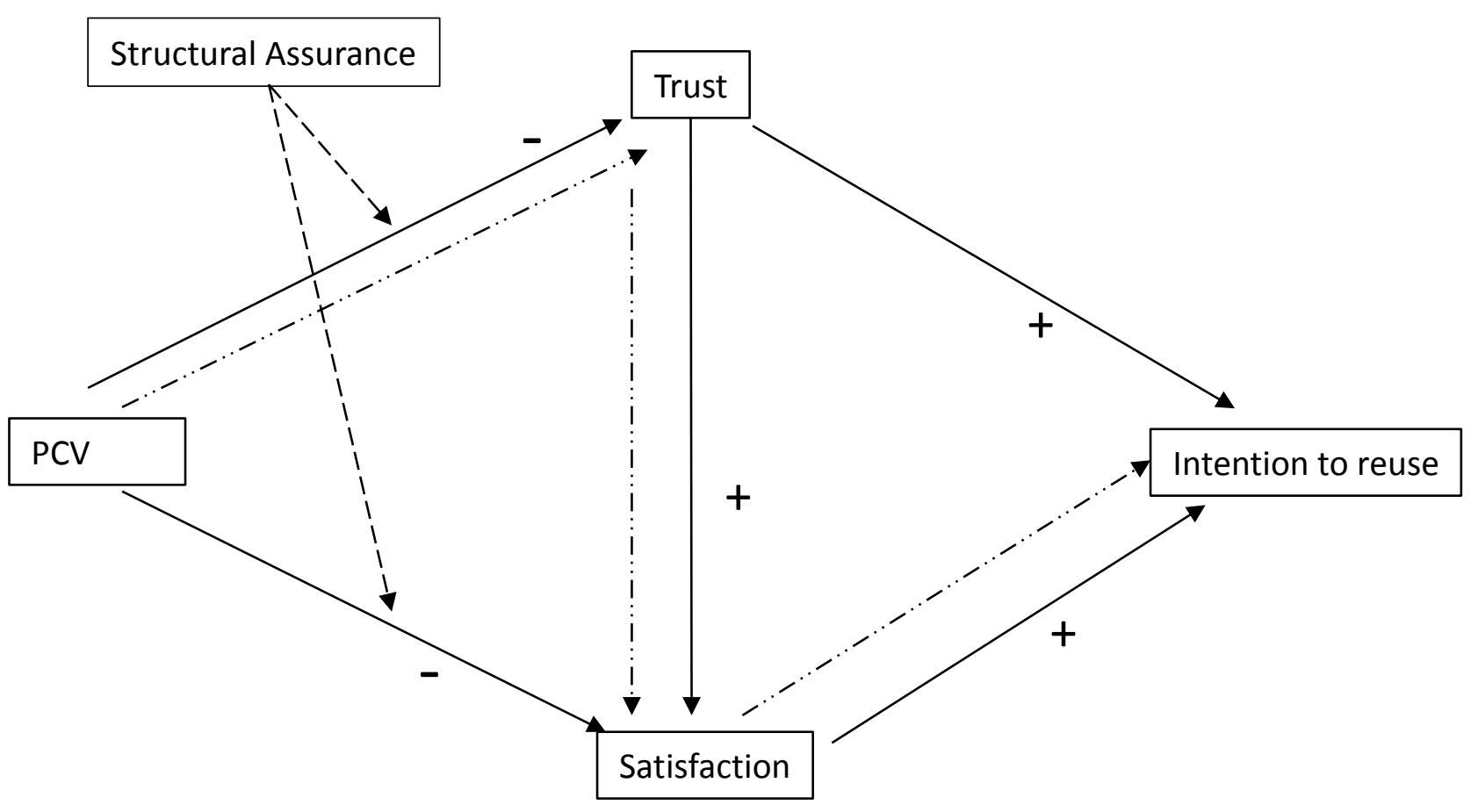

Moderating effect

Serial Mediation effect 
Figure. 2

Empirical Model

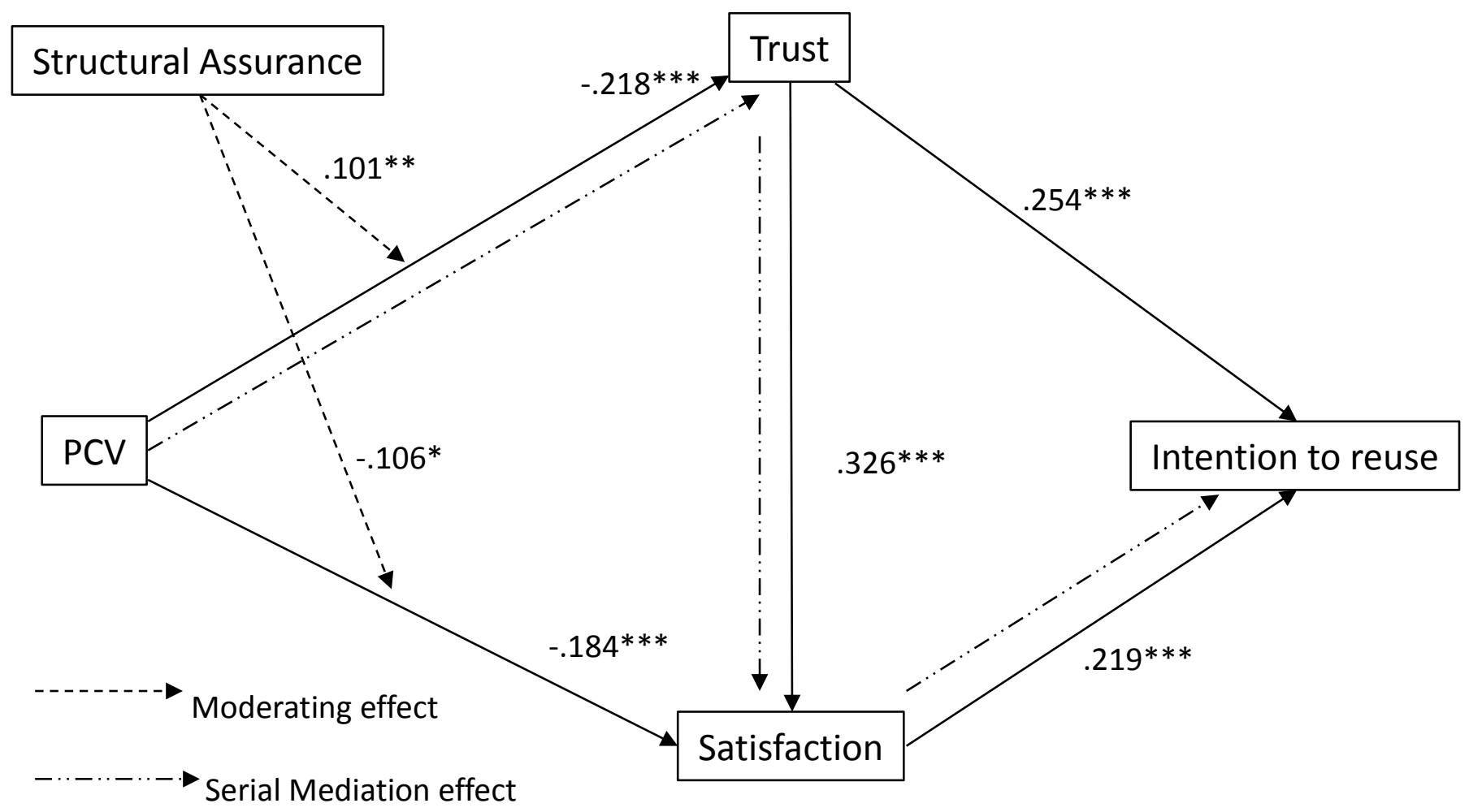

$* * * \mathrm{p} \leq 0.01, * * \mathrm{p} \leq 0.05, * \mathrm{p} \leq 0.10$ 
Figure 3

Moderating role of Structural Assurance in the PCV - Trust relationship

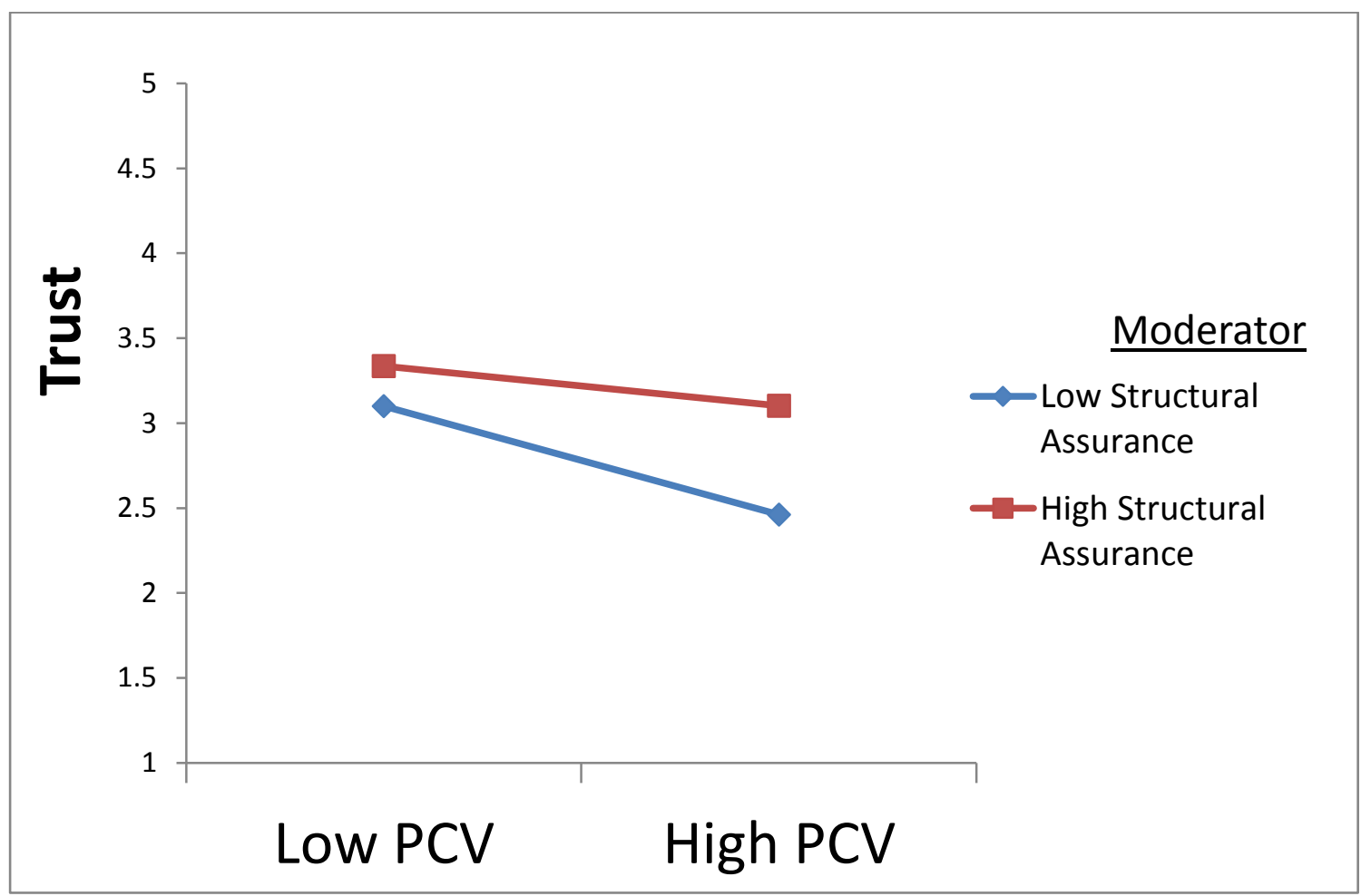


Figure 4

Moderating role of Structural Assurance in the PCV - Satisfaction relationship

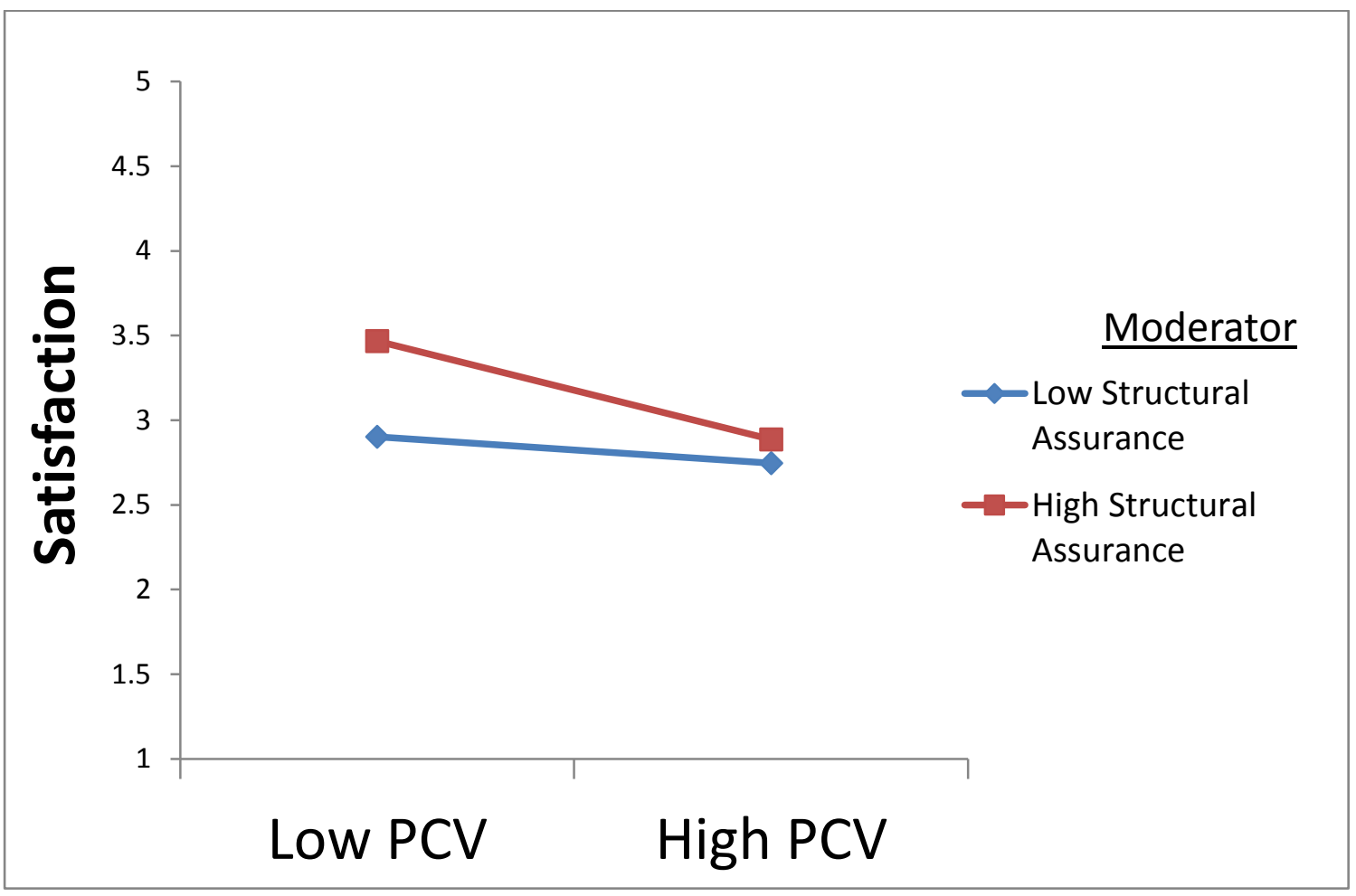


Appendix-1

Scale items used in the study

\begin{tabular}{|c|}
\hline $\begin{array}{l}\text { Intention to reuse } \\
\text { In the next few months I intend to use this website to the same extent that I am }\end{array}$ \\
\hline $\begin{array}{l}\text { In the next few months I intend to look at alternative websites more seriously as an option } \\
\text { than I am doing now (reverse scaled) }\end{array}$ \\
\hline $\begin{array}{l}\text { In the next few months I don't intend to cut back on my purchase of products from this } \\
\text { website }\end{array}$ \\
\hline Trust \\
\hline $\begin{array}{l}\text { There is no limit to the extent that this site will go towards solving any service problem that I } \\
\text { may have }\end{array}$ \\
\hline This site is genuinely committed to my satisfaction \\
\hline When this site makes a claim or promise about its service, it is probably true \\
\hline In my experience this site is very reliable \\
\hline I feel what to expect from this website \\
\hline Structural Assurance \\
\hline $\begin{array}{l}\text { The internet has enough safeguards to make me feel comfortable using it to transact personal } \\
\text { business }\end{array}$ \\
\hline $\begin{array}{l}\text { I feel assured that legal and technological structures adequately protect me from problems on } \\
\text { the internet }\end{array}$ \\
\hline $\begin{array}{l}\text { I feel confident that encryption and other technological advances on the internet make it safer } \\
\text { for me to do business here }\end{array}$ \\
\hline In general, the internet is now a robust and safe environment in which to transact business \\
\hline Satisfaction \\
\hline Overall I am satisfied by the service offered by the website \\
\hline The service offered through the website exceeds my expectations \\
\hline $\begin{array}{l}\text { The service offered through the website is close to the ideal level of service that can be } \\
\text { offered through a site like this }\end{array}$ \\
\hline Psychological Contract Violation - (Formative construct) \\
\hline $\begin{array}{l}\text { During all your transactions with this e-retailing website on approximately how many } \\
\text { occasions the items arrived later than what it was initially promised }\end{array}$ \\
\hline $\begin{array}{l}\text { During all your transactions with this e-retailing website on approximately how many } \\
\text { occasions the items you eventually received differed in quality from what was initially shown } \\
\text { in the website }\end{array}$ \\
\hline $\begin{array}{l}\text { During all your transactions with this e-retailing website on approximately how many } \\
\text { occasions you found it difficult to make a product complaint or refund claim to the e-retailer }\end{array}$ \\
\hline $\begin{array}{l}\text { During all your transactions with this e-retailing website on approximately how many } \\
\text { occasions the items were never delivered (though you were not charged) }\end{array}$ \\
\hline
\end{tabular}




\section{PCV Scenarios}

The following set of statements pertains to the experience with your most frequented e-retailing website. Please recollect your experience with this one website for the last one year and answer questions below. Kindly read the statements clearly. Please remember there are no right or wrong answers. Please give a tick $[\mathrm{V}]$ in the appropriate space provided below each statement

1. During all your transactions with this e-retailing website on approximately how many occasions the items arrived later than what was initially promised

Never in my experience

Once or twice at most

More than once but only on a few occasions

On several occasions

On most occasions.

2. During all your transactions with this e-retailing website on approximately how many occasions the items you eventually received differed in quality from what was initially shown in the website

Never in my experience

Once or twice at most

More than once but only on a few occasions

On several occasions

On most occasions.

3. During all your transactions with this e-retailing website on approximately how many occasions the items were never delivered (though you were not charged) Never in my experience

Once or twice at most

More than once but only on a few occasions

On several occasions

On most occasions.

4. During all your transactions with this e-retailing website on approximately how many occasions you found it difficult to make a product complaint or refund claim to the e-retailer Never in my experience

Once or twice at most

More than once but only on a few occasions

On several occasions

On most occasions. 